\title{
Kinetic and Thermodynamic Study for Fenton-Like Oxidation of Amaranth Red Dye
}

\author{
Z. M. Abou-Gamra \\ Chemistry Department, Faculty of Science, Ain-Shams University, Cairo, Egypt \\ Email: zanibabougamra@yahoo.com
}

Received 8 April 2014; revised 8 May 2014; accepted 28 May 2014

Copyright ( 2014 by author and Scientific Research Publishing Inc.

This work is licensed under the Creative Commons Attribution International License (CC BY). http://creativecommons.org/licenses/by/4.0/

(c) (i) Open Access

\begin{abstract}
Oxidation by Fenton like reactions $\left(\mathrm{Fe}^{3+} / \mathrm{H}_{2} \mathrm{O}_{2}\right)$ is economically process for destructive hazardous pollutants in waste water. The effects of different parameters such as, amaranth red dye, ferric chloride, hydrogen peroxide concentrations, $\mathrm{pH}$ value of solution, temperature and the presence of inorganic ions (carbonate, nitrate, chloride) on oxidative decolorization of amaranth were investigated. Amaranth degradation by $\left(\mathrm{Fe}^{3+} / \mathrm{H}_{2} \mathrm{O}_{2}\right)$ reagent was found to follow first order kinetic model. Under optimum condition, $\mathrm{pH}=2.6$ and $\left[\mathrm{FeCl}_{3}\right]=3.75 \times 10^{-4} \mathrm{~mol} \cdot \mathrm{dm}^{-3}$, the amaranth in aqueous solution with an initial concentration of $5 \times 10^{-5} \mathrm{~mol} \cdot \mathrm{dm}^{-3}$ was degraded by $95 \%$ within 6 minutes. Increasing temperature in the range of 298 - $308 \mathrm{~K}$ increases the rate of dye degradation. Thermodynamic constants, $\Delta H^{*}, \Delta S^{*}$ and $\Delta G^{*}$ were evaluated. The results implied that the oxidation process was favorable and endothermic.
\end{abstract}

\section{Keywords}

Amaranth Red, Decolorization, Kinetics, Fenton-Like

\section{Introduction}

The need of industry for dye has shown a high pollutant potential, specially the use of azodyes [1], for example, tartrazine [2], amaranth [3] and others. Amaranth is used as food dye; cosmetic dye and can applied for natural and synthetic fibers, leather, paper, phenol formaldehyde resins [4]. The FDA in the United States has banned amaranth and it is also banned in Russia, Norway and Austria [5]. Owing to their toxicity, many studies have been done to remove them from water source. Biological (biodegradation) [6] and chemical methods (chlorination, ozonation) [7] are the most frequently used methods for removal of dyes from effluent water streams. But, these traditional processes for treatment of the effluents prove to be insufficient to purify waste water after the different operations of waste waters dyeing and washing. 
Advanced oxidation processes (AOPs) are alternative methods for the complete degradation of dye. The usage of the advanced oxidation processes (AOPs) have improved during the last decade since they are able to eliminate the problem of dye destruction in aqueous systems. AOPs were based on the generation of very reactive species such as hydroxyl radicals $(\bullet \mathrm{OH})$ that oxidize a broad range of pollutants quickly and non-selectively. AOPs such as Fenton and Photo-Fenton catalytic reactions [8] [9], $\mathrm{H}_{2} \mathrm{O}_{2} / \mathrm{UV}$ processes [9].

The aim of this work was to find out the potential of Fenton-like for the decolorization of amaranth as model azo dye and examine the effect of the major system parameters on the decolorization kinetics of amaranth dye. Such parameters are the $\mathrm{pH}$, concentration of ferric chloride, $\mathrm{H}_{2} \mathrm{O}_{2}$, dye and temperature of ambient. Also the study gave attention to the effect some inorganic electrolytes.

\section{Experimental}

\subsection{Reagents and Materials}

All chemicals were of pure grade and were used without further purification. Amaranth Red purchased from Fisher Scientific company chemical manufacturing division Fair town, New Jersey (molecular weight $=604.47$, $\lambda_{\max }=520 \mathrm{~nm}$ ). The chemical structure and uv-vis spectrum of amaranth red dye is given in Figure 1. $\mathrm{FeCl}_{3}$, $\mathrm{NaCl}, \mathrm{NaNO}_{3}$ and $\mathrm{Na}_{2} \mathrm{CO}_{3}$ were purchased from Merck. Hydrogen peroxide solution (35\%) was of analytical grade. All solutions were prepared using bidistilled water. Stock solutions of dye $(1 \mathrm{mM}), \mathrm{FeCl}_{3}(10 \mathrm{mM})$ were prepared in $0.01 \mathrm{M}$ of $\mathrm{HCl}$. All experiments were performed at $\mathrm{pH}$ below 3.

\subsection{Kinetic Experiments}

The kinetic measurements were carried out spectrophotometrically using 292 Cecil spectrophotometer was equipped with constant temperature cell holder attached to thermostatic controlled bath with temperature stability of $\pm 0.1^{\circ} \mathrm{C}$. The reactants were thermostated for $15 \mathrm{~min}$, then mixed thoroughly and quickly transferred to an absorption cell. The progress of the reaction was monitored at $520 \mathrm{~nm}$. The $\mathrm{pH}$ of the reaction was adjusted using Griffin pH-meter fitted with a combined glass calomel electrode.

\section{Results and Discussion}

The present study concerns with the oxidative decolorization of amaranth by Fenton-like reaction. The absorbance of amaranth at $\lambda_{\max }=520 \mathrm{~nm}$ decreased with time as shown in Figure 2. The kinetics measurements were carried out under pseudo first order conditions, where hydrogen peroxide concentration was in excess than that of dye. The plot of logarithmic absorbance vs. time was linear. This indicates the pseudo first-order kinetics of the reaction with respect to the Amaranth concentration.

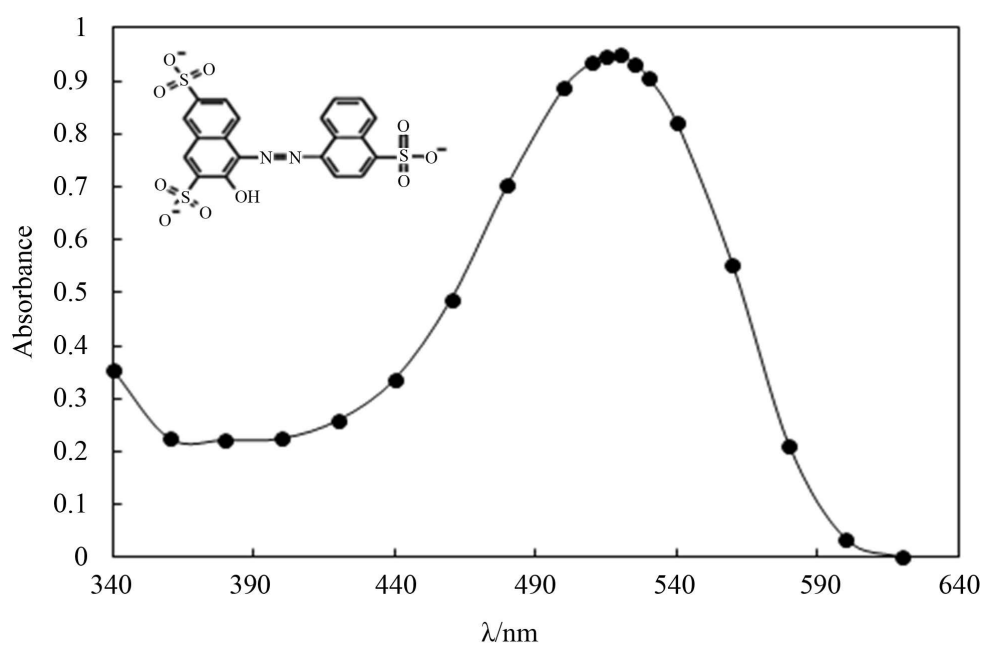

Figure 1. Chemical structure, uv-vis spectrum of amaranth red dye. [dye] $=5$ $\times 10^{-5} \mathrm{~mol} \cdot \mathrm{dm}^{-3}$. 


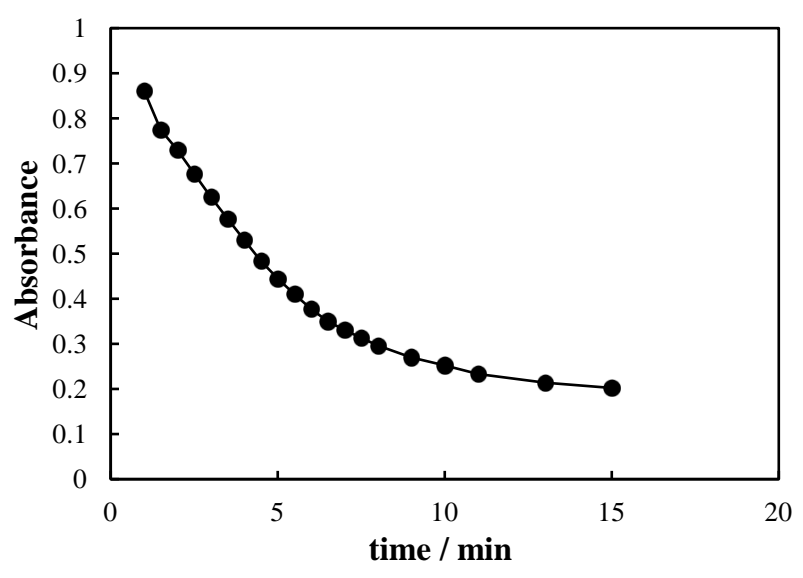

Figure 2. The change in absorbance of amaranth vs time at $\lambda$ $=520 \mathrm{~nm}$. [dye $]=5 \times 10^{-5} \mathrm{~mol} \cdot \mathrm{dm}^{-3},\left[\mathrm{H}_{2} \mathrm{O}_{2}\right]=5 \times 10^{-3}$ $\mathrm{mol} \cdot \mathrm{dm}^{-3},\left[\mathrm{Fe}^{3+}\right]=5 \times 10^{-4} \mathrm{~mol} \cdot \mathrm{dm}^{-3}$ and $\mathrm{pH}=2.6$.

\subsection{Effect of $\mathrm{pH}$}

Advanced oxidation processes are powerful alternative methods of wastewater treatment. This method based on the production of powerful oxidant, HO ( $\mathrm{E}=2.8 \mathrm{~V}$ versus NHE). These radicals are capable to degrade recalcitrant organic compounds under mild experimental conditions [10]. The general mechanism of Fenton reaction $[11]$ is

$$
\mathrm{Fe}^{2+}+\mathrm{H}_{2} \mathrm{O}_{2} \rightarrow \mathrm{Fe}^{3+}+\mathrm{HO}+\mathrm{HO}^{-}
$$

Then, $\mathrm{Fe}^{3+}$ ions can be reduced by excess $\mathrm{H}_{2} \mathrm{O}_{2}$ to form $\mathrm{Fe}^{2+}$ ions and more HO radicals. Second reaction is called Fenton-like [12] allowing $\mathrm{Fe}^{2+}$ regeneration leading to catalytic mechanism (reactions, 2 - 6),

$$
\begin{aligned}
& \mathrm{Fe}^{3+}+\mathrm{H}_{2} \mathrm{O}_{2} \leftrightarrow \mathrm{Fe}^{2+}+\mathrm{HO}_{2}+\mathrm{H}^{+} \mathrm{Fe}^{3+}+\mathrm{HO}_{2} \rightarrow \mathrm{Fe}^{2+}+\mathrm{O}_{2}+\mathrm{H}^{+} \\
& \mathrm{Fe}^{2+}+\mathrm{HO} \leftrightarrow \mathrm{Fe}^{3+}+\mathrm{OH}^{-} \\
& \mathrm{OH}+\mathrm{H}_{2} \mathrm{O}_{2} \leftrightarrow \mathrm{HO}_{2}+\mathrm{H}_{2} \mathrm{O} \\
& \mathrm{Fe}^{2+}+\mathrm{HO}_{2} \rightarrow \mathrm{Fe}^{3+}+\mathrm{HO}_{2}^{-} \\
& 2 \mathrm{HO}_{2} \rightarrow 2 \mathrm{HO} \\
& \text { dye }+\mathrm{HO} \rightarrow \text { product }
\end{aligned}
$$

As clear from above mechanism the amount of HO depends on the $\mathrm{pH}$ of solution. The effect of $\mathrm{pH}$ was studied in $\mathrm{pH}$ range of 2 - 3. The results showed that increasing $\mathrm{pH}$ from 2 to $2.6 \pm 0.1$ increases the observed rate constant, $\mathrm{k}_{\mathrm{obs}}$, from $0.45 \times 10^{-3} \mathrm{~s}^{-1}$ to $8.9 \times 10^{-3} \mathrm{~s}^{-1}$ (Figure 3). The drastic decrease in the rate of decolorization at $\mathrm{pH}=2$ is attributed to drastic reduction of hydroxyl radicals resulted from the stabilization of hydrogen peroxide. Also Figure 3 showed that increasing $\mathrm{pH}$ above 2.6 decreases the observed rate constant. Therefore, the optimal $\mathrm{pH}$ value for the decolorization of amaranth is 2.6. This is in agreement with earlier results [8] [11]-[15]. These studies showed that there is optimum $\mathrm{pH}$ value $(\mathrm{pH}=3)$.

\subsection{Effect of Ferric Chloride Concentration}

No reaction was observed between amaranth and hydrogen peroxide in absence of ferric ions. Ferric ion concentration shows acceleration effect on the decolorization rate of amaranth. Keeping temperature at $35^{\circ} \mathrm{C}$, [dye] $=5 \times 10^{-5} \mathrm{~mol} \cdot \mathrm{dm}^{-3}$ and $\left[\mathrm{H}_{2} \mathrm{O}_{2}\right]=5 \times 10^{-3} \mathrm{~mol} \cdot \mathrm{dm}^{-3}$ using different concentrations of ferric chloride namely, 1 $3.75 \times 10^{-4} \mathrm{~mol} \cdot \mathrm{dm}^{-3}$, the decolorization rate increased by increasing ferric ions concentrations. This is attributed to increase HO' concentrations. Above that concentration the rate decreased, Figure 4. This could be at- 


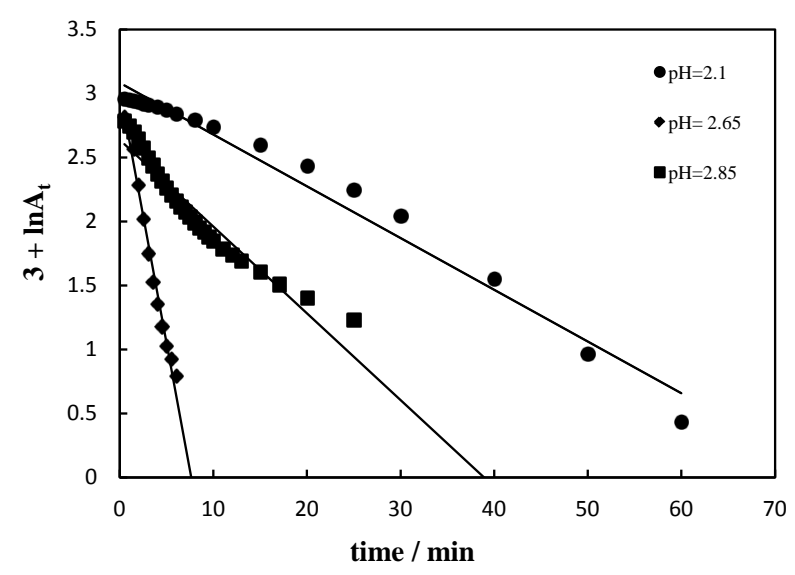

Figure 3. First order plots for decolorization of amaranth at various $\mathrm{pH}$. [dye] $=5 \times 10^{-5} \mathrm{~mol} \cdot \mathrm{dm}^{-3},\left[\mathrm{H}_{2} \mathrm{O}_{2}\right]=5 \times 10^{-3}$ $\mathrm{mol} \cdot \mathrm{dm}^{-3},\left[\mathrm{Fe}^{3+}\right]=5 \times 10^{-4} \mathrm{~mol} \cdot \mathrm{dm}^{-3}$ and $\mathrm{T}=35^{\circ} \mathrm{C}$.

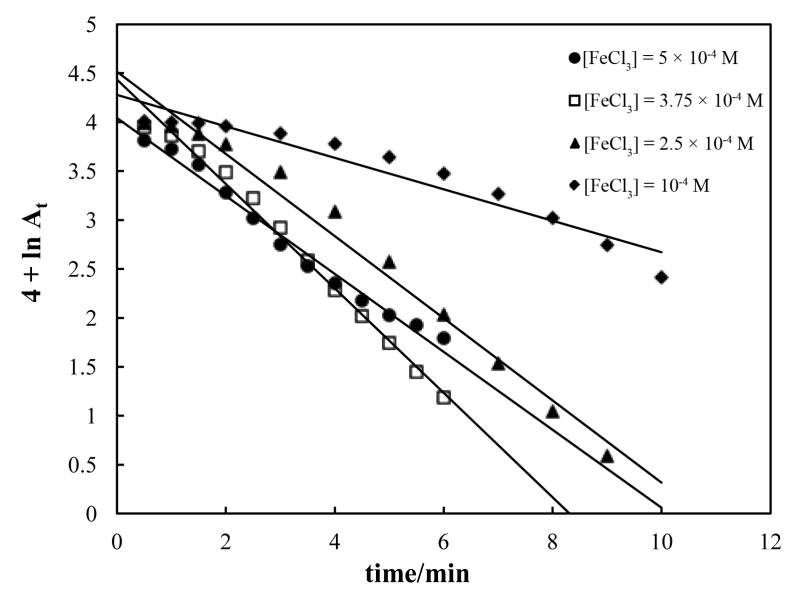

Figure 4. First order plots for decolorization of amaranth at various $\mathrm{Fe}^{3+}$ concentrations. [dye] $=5 \times 10^{-5} \mathrm{~mol} \cdot \mathrm{dm}^{-3},\left[\mathrm{H}_{2} \mathrm{O}_{2}\right.$ ] $=5 \times 10^{-3} \mathrm{~mol} \cdot \mathrm{dm}^{-3}, \mathrm{pH}=2.65$ and $\mathrm{T}=35^{\circ} \mathrm{C}$.

tributed to the increasing in $\left[\mathrm{Fe}^{3+}\right]$ increases $\left[\mathrm{Fe}^{2+}\right]$ which scavenging the $\mathrm{HO}$ [8] [15]. Maximum rate at $\left[\mathrm{Fe}^{3+}\right]=$ $3.75 \times 10^{-4} \mathrm{~mol} \cdot \mathrm{dm}^{-3}$, almost, 95\% color removed was observed. Khataee et al. [16] reported that increasing the concentration of $\mathrm{Fe}^{3+}$ ions increases the decolorization rate of brilliant blue and maximum rate was at $\left[\mathrm{Fe}^{3+}\right]=2 \times$ $10^{-4} \mathrm{~mol} \cdot \mathrm{dm}^{-3}$.

\subsection{Effect of $\mathrm{H}_{2} \mathrm{O}_{2}$ Concentration}

The effect of hydrogen peroxide concentration on the rate of decolorization of amaranth studied at $\mathrm{pH}$ equals 2 , [dye $]=5 \times 10^{-5} \mathrm{~mol} \cdot \mathrm{dm}^{-3}$ and $\left[\mathrm{Fe}^{3+}\right]=5 \times 10^{-4} \mathrm{~mol} \cdot \mathrm{dm}^{-3}$. Figure 5 showed that the decrease in dye concentration as function of time was dependent of hydrogen peroxide concentration. Increases of hydrogen peroxide concentrations in range of $5-25 \times 10^{-3} \mathrm{~mol} \cdot \mathrm{dm}^{-3}$ increases the rate constant of decolorization from $0.5 \times 10^{-3}$ to $2 \times 10^{-3} \mathrm{~s}^{-1}$. This is due to the increase of HO' radicals [8] [15]. Plot of $\ln \mathrm{k}_{\mathrm{obs}}$ versus $\ln \left[\mathrm{H}_{2} \mathrm{O}_{2}\right]$ yields straight line with slope of unity indicates the reaction is first order in hydrogen peroxide.

\subsection{Effect of Amaranth Concentration}

The effect of initial dye concentration of aqueous solution of amaranth on Fenton-like process was investigated since pollutant concentration is important parameter in wastewater treatment. Increasing the initial amaranth concentration from 2 to $4 \times 10^{-5} \mathrm{~mol} \cdot \mathrm{dm}^{-3}$ did not show any effect on the decolorization rate, Figure 6 . Also 


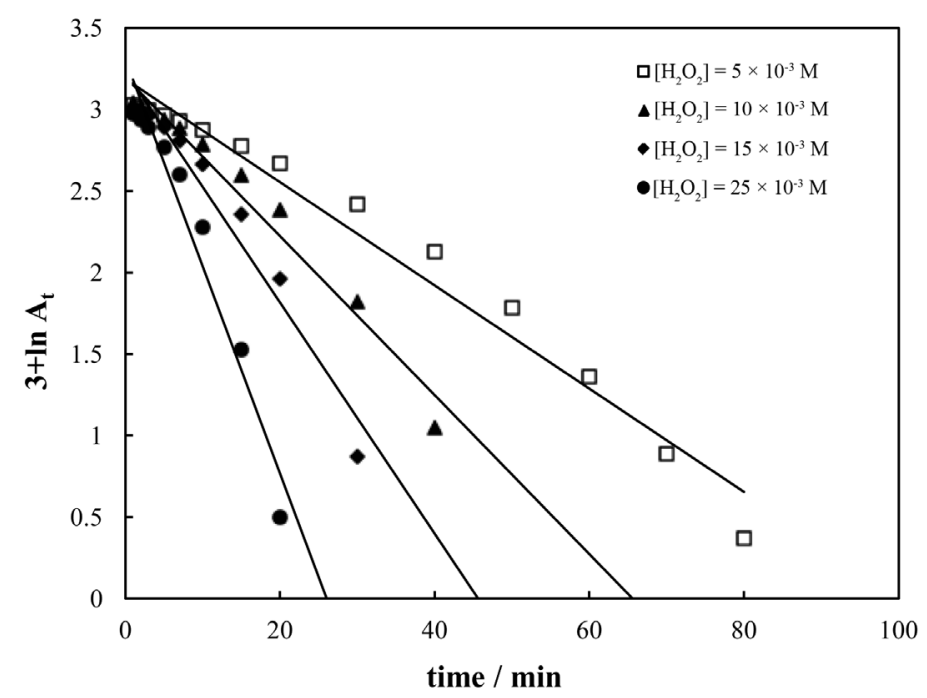

Figure 5. First order plots for decolorization of amaranth at various $\mathrm{H}_{2} \mathrm{O}_{2}$ concentrations. [dye] $=5 \times 10^{-5} \mathrm{~mol} \cdot \mathrm{dm}^{-3},\left[\mathrm{Fe}^{3+}\right]=5 \times 10^{-4} \mathrm{~mol} \cdot \mathrm{dm}^{-3}$, $\mathrm{T}=35^{\circ} \mathrm{C}$ and $\mathrm{pH}=2$.

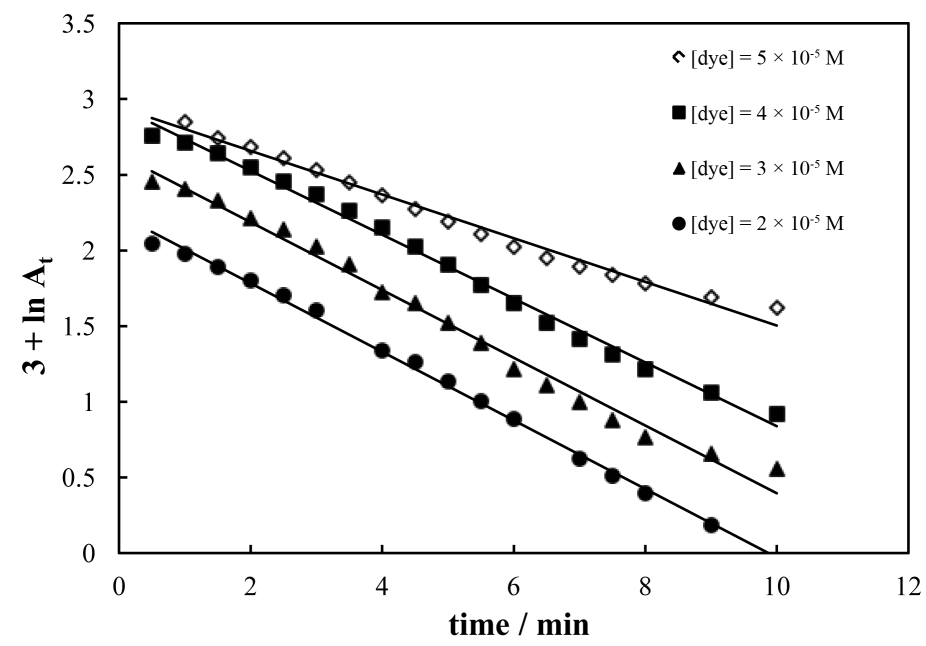

Figure 6. First order plots for decolorization of amaranth at various dye concentrations. $\left[\mathrm{H}_{2} \mathrm{O}_{2}\right]=5 \times 10^{-3} \mathrm{~mol} \cdot \mathrm{dm}^{-3},\left[\mathrm{Fe}^{3+}\right]=5 \times 10^{-4} \mathrm{~mol} \cdot \mathrm{dm}^{-3}$, $\mathrm{T}=30^{\circ} \mathrm{C}$ and $\mathrm{pH}=2.65$.

Figure 6 shows that increasing the concentration of dye above $\left(4 \times 10^{-5} \mathrm{~mol} \cdot \mathrm{dm}^{-3}\right)$ decrease the rate of decolorization. This attributed to relatively lower of $\mathrm{HO}$ results from the increasing of amaranth concentration while concentration of $\mathrm{H}_{2} \mathrm{O}_{2}$ and $\mathrm{Fe}^{3+}$ remains the same. The obtained results were in good agreement with earlier reported [11] [13]-[15].

\subsection{Effect of Temperature}

The variation of the temperature in range of 298 - $308 \mathrm{~K}$ increases the rate of decolorization of amaranth. No optimal temperature in this study was detected as opposed to the literature reports [17] [18] in which $30^{\circ} \mathrm{C}$ are stated as optimal temperature for Fenton oxidation. Another optimal temperature, $50^{\circ} \mathrm{C}$ was reported on decolorization of some dyes by Fenton-like reaction [8]. The activation energy was calculated from Arrhenius plot and Eyring equation and was found to be $104.79 \mathrm{~kJ} \cdot \mathrm{mol}^{-1}$. The other thermodynamic parameters are given in Table 1. As observed from Table 1 positive value of $\Delta \mathrm{S}^{*}$ indicates reaction is favor. The $\Delta \mathrm{H}^{*}$ positive value indicates that the process is endothermic. 


\subsection{Effect of Inorganic Anion Concentration}

Inorganic anions occur naturally in waste water (e.g. $\mathrm{NO}_{3}^{-}$) or may be added to facilitate the dyeing (e.g. $\mathrm{Cl}^{-}$ and $\mathrm{CO}_{3}^{2-}$ ). The presence of inorganic anions in textile wastewaters plays an important role in the oxidation kinetics of different dyes. Inorganic anions may induce or reduce the rate of oxidation.

\subsubsection{Influence of $\mathrm{NaNO}_{3}$ Concentration}

Decolorization rate of amaranth did not affect by addition of $\mathrm{NaNO}_{3}$ (Table 2).

\subsubsection{Influence of $\mathrm{Na}_{2} \mathrm{CO}_{3}$ Concentration}

Different concentrations of $\mathrm{Na}_{2} \mathrm{CO}_{3}$ were used to study the effect of carbonate ions on the oxidation of amaranth. Carbonate ions were present mainly as $\mathrm{H}_{2} \mathrm{CO}_{3}$, since the experiments were performed at $\mathrm{pH} \leq 3$. Presence of bicarbonate ions in the course of oxidation may decrease the decolorization rate due to scavenging of $\mathrm{OH}^{*}$ by $\mathrm{HCO}_{3}^{-}\left(\mathrm{HCO}_{3}^{-}+\mathrm{OH} \rightarrow \mathrm{CO}_{3}^{?-}+\mathrm{H}_{2} \mathrm{O}\right)$. Production of $\mathrm{CO}_{3}^{--}$which is less reactive than hydroxyl radical [19] lowered the levels of $\mathrm{OH}$ during the course of the reaction hence decreasing the decolorization rate. It was observed that the decolorization rate constant $\left(5.295 \times 10^{-3} \mathrm{~s}^{-1}\right)$ in the absence of carbonate ions decreased to 1.74 $\times 10^{-3} \mathrm{~s}^{-1}$ due to the presence of $8 \times 10^{-3} \mathrm{~mol} \cdot \mathrm{dm}^{-3} \mathrm{Na}_{2} \mathrm{CO}_{3}$, Table 2 .

\subsubsection{Influence of $\mathrm{NaCl}$ Concentration}

Addition of $0.085 \mathrm{~mol} \cdot \mathrm{dm}^{-3}$ of $\mathrm{NaCl}$ decreased rate constant from $5.32 \times 10^{-3} \mathrm{~s}^{-1}$ (in absence of chloride) to 1.6 $\times 10^{-3} \mathrm{~s}^{-1}$. The inhibitive effect of chloride can be explained by scavenging effect of chloride ion on $\mathrm{OH}$ (Equation (9)).

$$
\mathrm{Cl}+\mathrm{HO} \rightarrow \mathrm{ClOH}^{\cdot}
$$

Increasing the concentration of chloride up to $0.340 \mathrm{~mol} \cdot \mathrm{dm}^{-3}$ had no significant effect (Table 2). The obtained results were in good agreement with earlier reported [8] [11] [14].

Table 1. Thermodynamic parameters for decolorization of Amaranth by Fenton-like reagent.

\begin{tabular}{cc}
\hline parameters & value \\
$\mathrm{E}_{\mathrm{a}}$ & $104.79 \mathrm{~kJ} \cdot \mathrm{mol}^{-1}$ \\
$\Delta \mathrm{H}^{*}$ & $102.23 \mathrm{~kJ} \cdot \mathrm{mol}^{-1}$ \\
$\Delta \mathrm{S}^{*}$ & $38.76 \mathrm{~J} \cdot \mathrm{K}^{-1} \cdot \mathrm{mol}^{-1}$ \\
$\Delta \mathrm{G}^{*}$ & $90.29 \mathrm{~kJ} \cdot \mathrm{mol}^{-1}$
\end{tabular}

Table 2. Observed first order rate constants for the decolorization of Amaranth by Fenton-like reagent at temperature $=35^{\circ} \mathrm{C}$ at different concentration of inorganic anions.

\begin{tabular}{|c|c|c|}
\hline Inorganic electrolyte & Concentration $/ \mathrm{mol} \cdot \mathrm{dm}^{-3}$ & $\mathrm{k}_{\mathrm{obs}} \times 10^{3} / \mathrm{s}^{-1}$ \\
\hline \multirow{4}{*}{$\mathrm{NaNO}_{3}$} & 0 & 5.295 \\
\hline & 0.059 & 5.207 \\
\hline & 0.118 & 6.2 \\
\hline & 0.236 & 6.032 \\
\hline \multirow{3}{*}{$\mathrm{NaCl}$} & 0 & 5.322 \\
\hline & 0.085 & 1.6 \\
\hline & 0.170 & 1.928 \\
\hline \multirow{3}{*}{$\mathrm{Na}_{2} \mathrm{CO}_{3}$} & 0 & 5.295 \\
\hline & 0.004 & 3.848 \\
\hline & 0.008 & 1.740 \\
\hline
\end{tabular}




\section{Conclusion}

The decolorization kinetics of amaranth red in aqueous solution was studied using Fenton like reaction in dark environment. The results showed that the Fenton-like is powerful method for decolorization of amaranth red dye. The reaction was first order in dye and $\mathrm{H}_{2} \mathrm{O}_{2}$. The Fenton-like oxidation of amaranth red dye showed maximum rate at $\mathrm{pH}=2.6$ and $\left[\mathrm{Fe}^{3+}\right]=3.75 \times 10^{-4} \mathrm{~mol} \cdot \mathrm{dm}^{-3}$.

\section{References}

[1] Pereira, W.S. and Freire, R.S. (2006) Azo Dye Degradation by Recycled Waste Zero-Valent Iron Powder. Journal of the Brazilian Chemical Society, 17, 832-838. http://dx.doi.org/10.1590/S0103-50532006000500003

[2] Vidotti, E.C. and Rollemberg, M.C.E. (2006) Derivative Spectrophotometry: A Simple Strategy for Simultaneous Determination of Food Dyes. Química Nova, 29, 230-233. http://dx.doi.org/10.1590/S0100-40422006000200010

[3] Keck, A., Klein, J., Kudlich, M., Stolz, A., Knackmuss, H.J. and Mattes, R. (1997) Reduction of Azo Dyes by Redox Mediators Originating in the Naphthalenesulfonic Acid Degradation Pathway of Phingomonas Sp. Strain BN6. Environmental Microbiology, 63, 3684-3690.

[4] Shu, H.Y. and Huang, C.R. (1995) Degradation of Commercial Azo Dyes in Water Using Ozonation and UV Enhanced Ozonationprocess. Chemosphere, 31, 3813-3825. http://dx.doi.org/10.1016/0045-6535(95)00255-7

[5] Karkmaz, M., Puzenat, E., Guillard, C. and Herrmann, J.M. (2004) Photocatalytic Degradation of the Alimentary Azo Dye Amaranth Mineralization of the Azo Group to Nitrogen. Applied Catalysis B: Environmental, 51, 183-194. http://dx.doi.org/10.1016/j.apcatb.2004.02.009

[6] Ghodake, G., Jadhav, U., Tamboli, D., Kagalkar, A. and Govindwar, S. (2011) Decolorization of Textile Dyes and Degradation of Mono-Azo Dye Amaranth by Acinetobacter calcoaceticus NCIM 2890. Indian Journal of Microbiology, 51, 501-508. http://dx.doi.org/10.1007/s12088-011-0131-4

[7] Burkinshaw, S.M. and Kabambe, O. (2009) Attempts to Reduce Water and Chemical Usage in the Removal of Reactive Dyes: Part 1 Bis(Aminochlorotriazine), Dyes. Dyes Pigments, 83, 363-374. http://dx.doi.org/10.1016/j.dyepig.2009.06.003

[8] Medien, H.A.A. and Khalil, S.M.E. (2010) Kinetics of the Oxidative Decolorization of Some Organic Dyes Utilizing Fenton-Like Reaction in Water. Journal of King Saud University (Science), 22, 147-153.

[9] Elmorsi, T.M., Riyad, Y.M., Mohamed, Z.H. and Abd El Bary, H.M.H. (2010) Decolorization of Mordant Red 73 Azo Dye in Water Using $\mathrm{H}_{2} \mathrm{O}_{2} / \mathrm{UV}$ and Photo-Fenton Treatment. Journal of Hazardous Materials, 174, 352-358. http://dx.doi.org/10.1016/j.jhazmat.2009.09.057

[10] Parsons, S. (2004) Advanced Oxidation Processes for Water and Wastewater Treatment. IWA Publishing, London.

[11] Habib, Md., Ismail, I., Mahmood, A.J. and Ullah, Md. (2012) Decolorization and Mineralization of Brilliant Golden Yellow (BGY) by Fenton and Photo-Fenton Processes. African Journal of Pure and Applied Chemistry, 6, 153-158.

[12] Ensing, B., Buda, F. and Baerends, E.J. (2003) Fenton-Like Chemistry in Water: Oxidation Catalysis by Fe(III) and $\mathrm{H}_{2} \mathrm{O}_{2}$. Journal of Physical Chemistry A, 107, 5722-5731. http://dx.doi.org/10.1021/jp0267149

[13] Neamtua, M., Yediler, A., Siminiceanu, I. and Kettrup, A. (2003) Oxidation of Commercial Reactive Azo Dye Aqueous Solutions by the Photo-Fenton and Fenton-Like Processes. Journal of Photo-Chemistry and Photobiology A: Chemistry, 161, 87-93. http://dx.doi.org/10.1016/S1010-6030(03)00270-3

[14] Chen, C.-C., Wu, R.-J., Tzeng, Y.-Y. and Lu, C.-S. (2009) Chemical Oxidative Degradation of Acridine Orange Dye in Aqueous Solution by Fenton's Reagent. Journal of the Chinese Chemical Society, 56, 1147-1155.

[15] Hashemian, S., Tabatabbaee, M. and Gafari, M. (2013) Fenton Oxidation of Methyl Violet in Aqueous Solution. Journal of Chemistry, 2013, Article ID: 509097. http://dx.doi.org/10.1155/2013/509097

[16] Khataee, A., Vatanpour, V. and Farajzadeh, M. (2008) Remediation of the Textile Dye Brilliant Blue FCF from Contaminated Water via a Fenton-Like Reaction: Influence of Aromatic Additives. Turkish Journal of Engineering and Environmental Sciences, 32, 367-376.

[17] Guedes Anabela, M.F.M., Madeira Luis, M.P., Boaventura Rui, A.R. and Costa Carlos, A.V. (2003) Fenton Oxidation of Cork Cooking Wastewater-Overall Kinetic Analysis. Water Research, 37, 3061-3069. http://dx.doi.org/10.1016/s0043-1354(03)00178-7

[18] Ramirez, J.H., Costa, C.A. and Madeira, L.M. (2005) Experimental Design to Optimize the Degradation of the Synthetic Dye Orange II Using Fenton's Reagent. Catalysis Today, 107-108, 68-76. http://dx.doi.org/10.1016/j.cattod.2005.07.060

[19] Buxton, G.V., Greenstock, C.L., Helman, W.P. and Ross, A.B., (1988) Critical-Review of Rate Constants for Reactions of Hydrated Electrons, Hydrogen-Atoms and Hydroxyl Radicals $\left(\cdot \mathrm{OH} / \bullet \mathrm{O}_{-}\right)$in Aqueous-Solution. Journal of Physical and Chemical Reference Data, 17, 513-886. http://dx.doi.org/10.1063/1.555805 
Scientific Research Publishing (SCIRP) is one of the largest Open Access journal publishers. It is currently publishing more than 200 open access, online, peer-reviewed journals covering a wide range of academic disciplines. SCIRP serves the worldwide academic communities and contributes to the progress and application of science with its publication.

Other selected journals from SCIRP are listed as below. Submit your manuscript to us via either submit@scirp.org or Online Submission Portal.
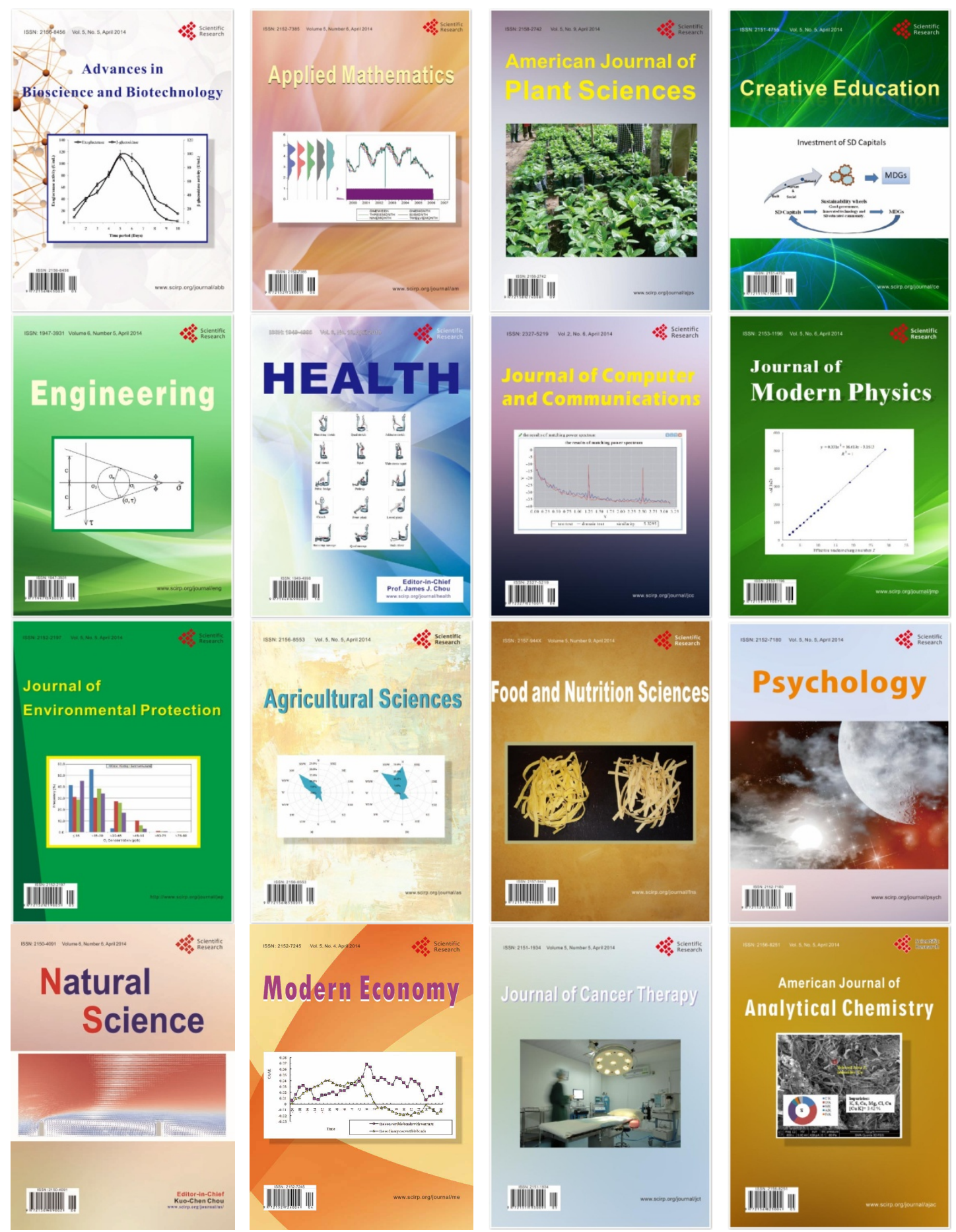